\title{
Antiphospholipid autoantibodies testing in women with unexplained infertility and recurrent first trimester abortion
}

\author{
*Nisreen K. Al-Bezrah, ABOG \\ Department of Obstetrics and Gynecology, Faculty of Medicine, Taif, Saudi Arabia
}

Address for Correspondence: Nisreen Khalid Aref AL Bezrah, Assistant Professor, Obstetric \&Gynecology Department, Medical College / Taif University, Saudi Arabia, email: nisreenaref@yahoo.com

\begin{abstract}
Objective: To assess the occurrence of antiphospholipid auto-antibodies (aPLA) in women suffering from unexplained infertility or recurrent first trimester abortion to evaluate their pathogenic role in these disorders. Setting: King Abdul Aziz Specialist Hospital, Taif, Saudi Arabia. Patients and Methods: Between June 2013 and December 2014, a prospective study was carried out on 20 women with unexplained fertility (group A), 20 women with recurrent first trimester abortion (group B), compared to 20 healthy women as control (group C). IgA, IgM, and IgG against phospholipids were detected in the sera of all cases. Results: It was found that $\operatorname{IgA} \operatorname{IgM}$ and $\operatorname{IgG}$ levels were significantly higher in group A, B when compared to group C. Venereal Diseases Research Laboratory (VDRL) test was positive in $2(10 \%)$ cases in group A and $3(15 \%)$ cases in group B but it was negative in group C. Lupus anticoagulant (LA), tested by the activated partial thromboplastin time (APTT), was prolonged in 4 (20\%) group A and 3 (15\%) cases in group B. Conclusion: From the results of this study it can be concluded that reproductive performance may be affected by the abnormal presence of antiphospholipid auto-antibodies.
\end{abstract}

Key words: Antiphospholipid Antibodies, Unexplained Infertility, Recurrent First Trimester Abortion

\section{Introduction}

The investigation of causes of infertility and fetal loss are begging to deal increasingly with immunological factors, and in particular, with the autoimmunity [1]. Antiphospholipid antibodies (aPLA) are immunoglobulin that interfere with one or more phospholipid-dependent coagulation tests which lead to thromboembolic predisposition. Patients with persistent elevated results are at risk of arterial and venous thrombosis, gestational loss and other complications [2]. It has become apparent that reproductive success may be affected by the presence of abnormal aPLA [3]. The association between recurrent pregnancy loss and autoimmune diseases has been recognized since Nilsson et al [4], who reported the association between the presence a PLA and adverse pregnancy outcomes. Younis et al [5] reported that the presence of aPLA which included the lupus anticoagulant (LAC) and anticardiolipin antibody (ACL) were the main cause recurrent abortion in apparently healthy women and the mechanism of action is not completely clear.

Manuscript Received: $4^{\text {th }}$ Sept 2015

Reviewed: $16^{\text {th }}$ Sept 2015

Author Corrected: $30^{\text {th }}$ Sept 2015

Accepted for Publication: $10^{\text {th }}$ Nov 2015
Mc Intry ${ }^{6}$ has reported that certain aPLA interferes in very early pregnancy, at the stage of fetal implantation, by imbedding normal reproductive event. These miscarriages or implantation failures may be related to pathological mechanism causing recurrent abortion, which is commonly diagnosed as infertility [7]. It has been underlined that in addition to recurrent pregnancy loss, the autoimmune system may be involved in other reproductive processes such as endometriosis, unexplained infertility and in-vitro fertilization (IVF) failure [8].

However, despite the current interest in immunological factors leading to unexplained infertility, the relationship between aPLA, which can be immunoglobulin G (IgG), IgM or IgA classes, and reproductive performance is still controversial [9].

The aim of this study was to assess the occurrence of antiphospholipid antibodies in women suffering from unexplained infertility or recurrent first trimester abortion to evaluate their pathogenic role in these disorders. 


\section{Patients and Methods}

This prospective study was conducted in Obstetrics and Gynecology Department, King Abdul Aziz Specialist Hospital (500 beds), Taif, Saudi Arabia. Between June 2013 and December 2014, 60 patients were recruited from women attending the gynecological, infertility and recurrent pregnancy loss clinics.

All cases were subjugated to the following: a full clinical history, medical and gynecological examinations to exclude cases that may invalidate the results of immunoglobulin. Cases included in the study have been classified into three groups:

Group A: This group. Comprised 20 women with unexplained infertility. Their ages ranges from 22 to 34 years with a duration of marriage ranging between 4 to 10 years. All patients in this group had experienced a variable period of infertility and had undergone an intensive infertility evaluation without evidence of any diagnostic abnormality.

The fertility evaluation of women included confirmation of ovulation, normal hysterosalpingogram, normal laparoscopy findings, and negative cervical cultures and in phase endometrial biopsy specimen and the male partners were having at least two normal seminograms.

Group B: Included 20 patients who had recurrent first trimester abortion with no previous history of live births for at least two years. Their ages ranged from 22 to 35 years. Repeated first trimester pregnancy loss is defined as the occurrence of three or more clinically recognized losses before 12 weeks from the last menstrual period which are consecutive and spontaneous[10]. Cytogenetic analysis revealed normal karyotyping results for all cases in this group.

Group C: Included 20 fertile women who were healthy without history of autoimmune disease or pregnancy loss.

\section{Methods}

Blood sampling processing: Blood samples were obtained for activated partial thromboplastic time, dilute Russell viper venom time and anticardiolipin antibody (IgA, IgM, and $\operatorname{IgG}$ ). Blood samples were divided equally and put in 2 test tubes, the first was planned for serum testing and the second was citrated tube for full separated plasma. An activated partial

\section{Original Research Article}

thromboplastic time test was done immediately on aliquot puff plasma. The remaining plasma was frozen at $-70^{\circ} \mathrm{C}$ for subsequent testing for dilute Russell viper venom time. Serum was separated from the cell mass and frozen at $-70^{\circ} \mathrm{C}$ to determine the anticardiolipin antibody isotypes by enzyme-linked immunosorbent assay (ELISA).

1) Evaluation of partial thromboplastic time (APTT) : Platelet-poor plasma was incubated for 3 minutes at $37^{\circ} \mathrm{C}$ with activated partial thromboplastin time reagent (Auto-aPT; Organ Teknika, Durham, North Carolina) and the time to clot formation was measured by standard procedure (Coagumate/2000, Organ Teknika). The activated partial thromboplastin time test was preformed according to the method of Proctor and Rppaport [11]. A value that was 2 or more standard deviation above the mean for healthy controls was considered abnormal.

2) Evaluation of Dilute Russell Viper Venom Time: Platelet-poor plasma $(100 \mu \mathrm{L})$ was added to a mixture of dilute phospholipid (1/400 dilution Rabbit Brain Cephalin; Sigma Chemicals, St. Louis, Missouri) and $200 \mu \mathrm{L}$ Russell's Viper Venom (1/40 000 dilution of 1 mg crude venom; Sigma Chemicals). After 1 minute, $100 \mu \mathrm{L}$ calcium ions $(0.25 \mathrm{mmol} / \mathrm{L})$ were added and the time for clot formation was determined. The established range, based on frozen samples from 50 healthy, nonsmoking, non pregnant persons of both sexes taking no medications was 26 to 32 seconds (mean $\pm 2 \mathrm{SD}$ ).

3) Evaluation of Anticardiolipin antibodies: Anticardiolipin antibodies (IgA, $\operatorname{IgG}$ and $\operatorname{IgM}$ ) were measured in duplicate using the commercial anticardiolipin antibody ELISA kit (REAADS Medical Products, Westminster, Colorado). Briefly, serum samples, control sera, and calibrator sera were diluted 1:50 in sample diluent $(0.01 \mathrm{~mol} / \mathrm{L}$ phosphate-buffered saline, $\mathrm{pH} 7.4$, containing $10 \%$ bovine serum). One hundred $\mu \mathrm{L}$ of diluted serum was incubated in duplicate wells of 96-well plates coated with beef heart cardiolipin (diphosphatidyl glycerol) for 15 minutes at room temperature.

The serum was removed and the wells were washed four times with phosphate-buffered saline. One hundred $\mu \mathrm{L}$ of a prediluted horseradish peroxidase-conjugated goat antihuman IgG or IgM or Rabbit anti-IgA was added to each well and incubated for 15 minutes at room temperature. After washing, $100 \mu \mathrm{L}$ of a $1: 1$ substrate mixture of tetramethylbenzidine and $\mathrm{H}_{2} \mathrm{O}_{2}$ was 


\section{Original Research Article}

added to the micro wells and incubated for 10 minutes at room temperature. Color development was stopped by addition of $100 \mu \mathrm{L}$ of $2.5 \mathrm{~N} \mathrm{H}_{2} \mathrm{SO}_{4}$ and the absorbance at $450 \mathrm{~nm}$ was measured using an Emax micro titer plated reader (Molecular Devices, Menlo Park, California).

The values of anticardiolipin antibody activity for each sample were calculated from calibrator sera according to the manufacturer's instruction. This assay was standardized relative to the international reference preparations (original 1984 set) obtained from the AntiPhospholipid Standardization Laboratory, University of Louisville, Louisville, Kentucky. The normal cutoff value of the assay (23 units $\operatorname{IgG}, 11$ units $\operatorname{IgM}$ ) was defined as the mean IgG or IgM units plus two standard deviations of a healthy patient group. Immunoglobulin A anticardiolipin antibody activity was assessed using REAADS IgA anticardiolipin antibody test kit. A positive level (22 units) was defined as the mean plus three standard deviations of a healthy patient group.

Statistical Analysis: A statistical analysis was performed using the unpaired student's t-test. The relationship between the parameters analyzed was assessed using the linear regression method. Data were presented as mean $\pm \mathrm{SD}$, unless otherwise indicated. $\mathrm{P}<0.05$ was considered to be statistically significant.

\section{Results}

This study was carried out on 40 patients with either unexplained infertility or recurrent first trimester abortion and 20 and 20 age and sex matched normal fertile cases as control group. Twenty women with unexplained infertility (group A), their ages ranged from 22 to 34 years with a mean of $27.4 \pm 3.12$ years and a duration of marriage ranged from 4 to 8 years with a mean of $6.1 \pm 1.2$.

Twenty women with recurrent first trimester abortion (group B), their ages ranged from 22 to 36 years with a mean of $29.4 \pm 4.3$ years and the mean number of pregnancy loss in this group was $3.25 \pm 1.2$. Twenty healthy fertile women without a history of autoimmune diseases (control group), their ages ranged between 19 to 30 years with a mean of $25.4 \pm 2.7$ years. The result of our study showed that in group A the serum IgA, IgM and IgG levels were significantly higher than those of group C (control group) (Table 1). In group B the serum IgA, IgM and IgG levels were significantly higher than those of group $\mathrm{C}$ (Table 2). The activated partial thromboplastin time was higher in group A than in group $\mathrm{C}$ but with no significant difference (Table 3), but it was significantly higher in group B than in group C (Table 4). Table (5) summarizes the total number and percentage of abnormal tests in the studied groups. It shows that VDRL was positive in 2 patients of group A (10\%) and in 3 patients in group B (15\%) but it was negative in group C. While APTT was abnormally prolonged in $4(20 \%)$ cases in group A and $3(10 \%)$ cases in group B compared to normal test in the control group. There was a difference between the number of the patients showing abnormal test results in the study and control groups. The difference was highly significant except APTT there was no significant difference between them.

Table 1: Comparison between group $A$ and group $\mathrm{C}$ as regard to $\operatorname{IgA}$, IgM and $\operatorname{IgG}$.

\begin{tabular}{|c|c|c|c|c|c|}
\hline & \multicolumn{2}{|c|}{ Group A } & \multicolumn{2}{c|}{ Group C } & \multirow{2}{*}{ P } \\
\cline { 2 - 5 } & Mean & SD & Mean & SD & $<0.01$ \\
\hline $\operatorname{IgA}(\mathrm{gm} / \mathrm{L})$ & 2.27 & \pm 0.23 & 2.06 & \pm 0.14 & $<0.001$ \\
\hline $\operatorname{IgM}(\mathrm{mg} / \mathrm{L})$ & 2.32 & \pm 0.18 & 1.91 & \pm 0.2 & $<0.001$ \\
\hline $\operatorname{IgG}(\mathrm{gm} / \mathrm{L})$ & 14.5 & \pm 0.87 & 13.6 & \pm 0.63 & $<$ \\
\hline
\end{tabular}

$\operatorname{Ig} A=$ Immunoglobulin A, IgM =Immunoglobulin $M, \operatorname{Ig} G=$ Immunoglobulin $G, P<0.05=$ Significant .

Table-2 : Comparison between group B and Group C as regard to IgA, IgM and IgG.

\begin{tabular}{|c|c|c|c|c|c|}
\hline & \multicolumn{2}{|c|}{ Group B } & \multicolumn{2}{c|}{ Group C } & \multirow{2}{*}{ P } \\
\cline { 2 - 5 } & Mean & SD & Mean & SD & $<0.001$ \\
\hline $\operatorname{IgA}(\mathrm{gm} / \mathrm{L})$ & 2.61 & \pm 0.32 & 2.26 & \pm 0.2 & $<0.001$ \\
\hline $\operatorname{IgM}(\mathrm{mg} / \mathrm{L})$ & 2.88 & \pm 0.46 & 1.36 & \pm 0.33 & $<0.01$ \\
\hline $\operatorname{IgG}(\mathrm{gm} / \mathrm{L})$ & 15.34 & \pm 1.38 & 14.11 & \pm 0.77 & \\
\hline
\end{tabular}

$\operatorname{Ig} A=$ Immunoglobulin A, IgM =Immunoglobulin $M, \operatorname{Ig} G=$ Immunoglobulin $G, P<0.05=$ Significant . 
Original Research Article

Table-3: Activated partial thromboplastin time in group A versus group C

\begin{tabular}{|c|c|c|c|c|c|}
\hline & \multicolumn{2}{|c|}{ Group A } & \multicolumn{2}{c|}{ Group C } & \multirow{2}{*}{ P } \\
\cline { 2 - 5 } & Mean & SD & Mean & SD & $>0.05$ \\
\hline APTT (seconds) & 38.11 & \pm 3.89 & 36.26 & \pm 1.53 & $>0.26$ \\
\hline
\end{tabular}

APTT $=$ Activated Thromboplastin Time, $P=$ Non significant

Table4. Activated partial thromboplastin time in group B versus group C

\begin{tabular}{|l|c|c|c|c|c|}
\hline \multirow{2}{*}{} & \multicolumn{2}{|c|}{$\begin{array}{c}\text { Group B } \\
\text { (No. 20) }\end{array}$} & \multicolumn{2}{c|}{$\begin{array}{c}\text { Group C } \\
\text { (No. 20) }\end{array}$} & \multirow{2}{*}{ P } \\
\cline { 2 - 5 } & Mean & SD & Mean & SD & \\
\hline APTT (seconds)* & 41.76 & \pm 2.26 & 38.9 & \pm 1.08 & $<0.001$ \\
\hline
\end{tabular}

APTT $=$ Activated Thromboplastin Time, $P<0.05=$ Significant

Table-5: Frequency of positive ant phospholipid antibody test results in the studied groups.

\begin{tabular}{|c|c|c|c|c|c|c|c|c|}
\hline & \multicolumn{2}{|c|}{$\begin{array}{c}\text { Group A } \\
\text { (No.20) }\end{array}$} & \multicolumn{2}{c|}{$\begin{array}{c}\text { Group B } \\
\text { (No. 20) }\end{array}$} & \multicolumn{2}{c|}{$\begin{array}{c}\text { Group C } \\
\text { (No. 20) }\end{array}$} & \multicolumn{2}{c|}{ P } \\
\cline { 2 - 9 } & $\begin{array}{c}\text { Abnorm } \\
\text { al Tested } \\
\text { no. }\end{array}$ & $\begin{array}{c}\text { Abnorm } \\
\text { al Test } \\
(\%)\end{array}$ & $\begin{array}{c}\text { Abnorm } \\
\text { al Tested } \\
\text { no. }\end{array}$ & $\begin{array}{c}\text { Abnorm } \\
\text { al Test } \\
(\%)\end{array}$ & $\begin{array}{c}\text { Abnorm } \\
\text { al Tested } \\
\text { no. }\end{array}$ & $\begin{array}{c}\text { Abnorm } \\
\text { al Test } \\
(\%)\end{array}$ & A vs C & B vs C \\
\hline IgA(gm/L) & $9 *$ & $45 \%$ & 11 & $55 \%$ & 1 & $5 \%$ & 0.003 & 0.0005 \\
\hline IgM(mg/L) & 15 & $75 \%$ & 16 & $80 \%$ & 0 & $0 \%$ & $<0.001$ & $<0.001$ \\
\hline IgG(gm/L) & 17 & $85 \%$ & 18 & $90 \%$ & 2 & $10 \%$ & $<0.001$ & $<0.001$ \\
\hline $\begin{array}{c}\text { VDRL } \\
\text { antibodies }\end{array}$ & 2 & $10 \%$ & 3 & $15 \%$ & 0 & $0 \%$ & $<0.001$ & $<0.001$ \\
\hline $\begin{array}{c}\text { APTT } \\
\text { (seconds) }\end{array}$ & 4 & $20 \%$ & 3 & $15 \%$ & 0 & $0 \%$ & 0.03 & 0.07 \\
\hline
\end{tabular}

$\operatorname{Ig} A=$ Immunoglobulin $A, \operatorname{Ig} M=$ Immunoglobulin $M, \operatorname{Ig} G=$ Immunoglobulin $G, V D R L=$ Venereal Disease Research Laboratory, APTT = Activated Thromboplastin Time.

\section{Discussion}

In the study, we aimed at detection aPLA in the sera of first trimester abortion and compare them with control group without history of autoimmune disease to find the relation between these auto-antibodies and an abnormal reproductive performance.

This study has confirmed the association between the presence of abnormal auto-antibodies and the repeated pregnancy wastage and unexplained infertility, hence the importance of their testing for assessment in risky patients. This finding is in agreement with that reported by Lubbe et al [12] and Branch et al [13]. In recent years various types of reproductive failure have come to be considered as having an immune component. Immunologic effects are important at many levels in the reproductive process, including fertilization, implementation and the development of the placenta [14]. Ant phospholipid antibodies have been particularly associated with fetal loss and there is primarily evidence that auto-antibody profile can be correlated with reproductive failure. However, despite the current interest in immunological factors leading to unexplained infertility, the relationship between aPLA and reproductive performance is still controversial. ${ }^{9}$ The present results concern the determination of organspecific aPA in fertile and infertile women. The results show an increased incidence of aPLA antibodies in the group with unexplained infertility, which is in agreement with other published data [15].

The results of the current study showed that group A and $\mathrm{B}$ patients exhibited an unusual incidence of gammopathies. Serum IgA, IgG and IgM levels against phospholipids in both groups were found to be higher than their levels in control group. This result is in agreement with that reported by Gleicher et al [16]. who found an unusual patients with unexplained infertility and 11 out of 24 patients with unexplained pregnancy 


\section{Original Research Article}

wastage. The same result was reported by Kutteh et al [17]. However, Fisch et al [18] affirmed that the increased circulating aPA level in fertile patients may be related to IVF treatment, however, recently, it has been suggested that increased circulating aPA concentrations are no dependent on the treatment but must be considered in relation to the infertile state [19]. The rationale for the role of aPA in infertility may be merely speculative [20]

Proposed theories include inhibition of prostacyclin ratio [21], an increase in platelet activation [22] and a decrease in the activation of the antithrombotic action of protein C [23]. Furthermore, it has been shown that the attachment of aPA to surface phospholipids on the trophoblast may result in direct cellular injury, with inhibition of the cytotrophoblastic conversion to syncytiotrophoblast [24]. Lupus anticoagulant antibodies could be detected by prolongation of the activated partial thromboplastin time [25].

Although the cause of fetoplacental pathology in the presence of lupus anticoagulant phenomenon is still unknown, it is likely that there is a thrombotic tendency involving the decidual and placental blood vessels which is responsible for the infarction and necrosis that have been described in these cases [4] In the present study the mean APTT of cases in group A and B was significantly higher than in control group.

Gleicher et al [16] studied lupus anticoagulant by APTT values which were abnormal in only 3 out of 26 patients with unexplained infertility and 2 out of 24 patients with pregnancy wastage. Rote et al [26] found that APTT values were abnormally prolonged in 45 out of 47 patients with unexplained pregnancy wastage.

However, Greagh et al [27] reported that 7 out of 35 patients with unexplained pregnancy wastage had prolonged partial thromboplastin time. In the present study VDRL was positive in only 2 patients $(10 \%)$ in group A and in 3 patients (15\%) in group B and it was negative in all cases of group $\mathrm{C}$.

This result is in agreement with that of Cowchock et al [29] who found 2 cases with false positive VDRL result out of 61 cases with unexplained losses.

Conclusion, the role of antiphospholipid autoantibodies remains to be elucidated, but their importance in unexplained infertility or recurrent first trimester abortion is clear, providing an approach for therapeutic intervention. Exploring the role of aPL in reproduction may provide a novel strategy for better understanding maternal-fetal interactions in the uterus.

Additional studies are needed to develop scientific rational for the effect of antiphospholipid antibodies on the reproductive performance of women and if there is a beneficial effect of treating.

\section{Reference}

1. Radojcic L, Marjanovic S, Vicovac L and Kataranovski M. Anticardiolipin antibodies in women with unexplained infertility. Physiol Res 2004; 53:9196.

2. Lockshin MD, Qamar $T$ and Levy RA. Anticardiolipin and related antibosies: thrombosis and fetal death. In: Scott JS, Bird HA, editors. Pegnancy, autoimmunity and connective tissue disorders. Oxford University Press 1990;185-211.

3. Carp, H. J. A., and Y. Shoenfeld. "Anti-phospholipid antibodies and infertility.Clinic rev. Allerg . immunol. (2007) 32: 159-161.doi 10.1007/s12016-007-0010-2.

4. Gupta, Sajal, et al. "The role of oxidative stress in spontaneous abortion and recurrent pregnancy loss: a systematic review. Obstetrical \& gynecological survey $62.5 \quad$ (2007): 335-347.doi: 10.1097/01.ogx.0000261644.89300.df.

5. Younis JS, Ohel G, Bernner B, Haddad S, Lanir N, Ben-Ami M. The effect of thrombophylaxis on pregnancy outcome in patients with recurrent pregnancy loss associated with factor $\mathrm{V}$ Leiden mutation. BJOG 2000; 197:153-159. doi: $10.1111 /$ j.14710528.2000.tb13240.x

6. Mc Intry J. Antiphospholipid antibodies in implantation failure. Am J Repro Immunology 2003; 107(3):415-9. doi: 10.1034/j.1600-0897.2003.01197.x

7. Birkenfeld A, Mukaida T, Minichiello L, Jackson M, Kase NG, Yemini M. Incidence of autoimmune antibodies in failed embryo transfer cycles. Am J Repeo Immunol 1994;31:65-8. doi: $10.1111 / \mathrm{j} .1600-$ 0897.1994.tb00848.x

8. Geircger N, Pratt D and Dudkiewicz A. What we really know about autoantibody abnormalities and reproductive failure: A Critical review. Autoimmunity 1973; 16:115-140. 


\section{Original Research Article}

9. Balasch J, Montserrat $\mathrm{C}$ and Fabregues F. Antiphospholipid antibodies and human reproductive failure. Hum Reprod 1996; 11:2310-2315.

10. Wilcox AJ, Weiberg CR, O'Connor JF et al. Incidence of early loss of pregnancy. $N$ Engl J Med 1988; 319:18. doi: 10.1056/NEJM198807283190401

11. Proctor RR and Rappaport SI. The partial thromboplastin time with kaolin: a simple screening test for first stage plasma clotting factor deficiencies. Am J Clin Pathol 1961; 36:212-216.

12. Lubbe WF, Butler WS, Palmer SJ and Liggins GC. Lupus anticoagulant in pregnancy. BJOG 1984; 357-63. doi: 10.1111/j.1471-0528.1984.tb05923.x

13. Branch DW, Scott JR, Kochemour $\mathrm{Nk}$ and Hershogold E. Obstetric complications associated with lupus anticoagulant. $N$ Engl J Med 1986;313:13221326.

14. Billingham RF and Head JR. Current trends in reproductive immunology an overview. J Rep Immunol 1981; 3:253-265. doi: 10.1056/NEJM198511213132104

15. Roussev RG, Kadaider BD, Price DE, Coulman CB. Laboratory evaluation of women experiencing reproductive failure. Am J Repord Immunol 1996; 35:415-420. doi: 10.1111/j.1600-0897.1996.tb00503.x

16. Gleicher N, El Roely A, Confino E, and Friberg J. Reproductive failure because of auto-immune antibodies: unexplained infertility and pregnancy wastage. Am J Obstet Gynecol 1986;160:1376-1385. doi: http://dx.doi.org/10.1016/0002-9378(89)90858-2

17. Kutteh WH, Lyda EC, Abraham SM and Wacholtz MC. Association of anticardiolipin antibodies and pregnancy loss in women with systemic lupus erythromatosis. Fertil Steril 1993;60:449-455.

18. Fisch B, RIkover Y and Shobat L. The relationship between in virto fertilization and naturally occurring antibodies: Evidence of increased production of antiphospholipid antibodies. Fertil Steril 1991;56:718724.

19. Royburt M, Yron I and Fisch B. Autoimmune disorders and reproductive failure. Hum Reprod 1996;11:1138-1139.
20. Battaglia C, Sgarbi L and Salvatori M. Increased anticardiolipin antibodies are positively related to pulsatility index in unexplained infertility. Hum Reprod 1998; 13:3487-3491. doi: 10.1093/humrep/13.12.3487

21. Bouvier S, Cochery-Nouvellon E, Lavigne-Lissalde $\mathrm{G}$, et al. Comparative incidence of pregnancy outcomes in treated obstetric antiphospholipid syndrome: the NOH-APS observational study. Blood J. 2014; 123(3):404-13. doi: http://dx.doi.org/10.1182/blood2013-08-522623

22. Harris EN, Gharani AE and Hefge U. Anticardiolipin antibodies in autoimmune thrombocytopenic purpura. Br J Hematol 1985; 59:231234. doi: 10.1111/j.1365-2141.1985.tb02989.x

23. Cariou R, Tobelem $G$ and Bellucci S. Effect of lupus anticoagulant on antithrombogenic properties of endothelial cells: inhibition of thrombomodulin dependent protein C activation. Thrombo Hemost 1988; 69:54-58.

24. Kowalik A, Vichnin M and Chig L. Midfollicular anticardiolipin and antiphophatidylserine antibody titers do not correlate with in virto fertilization outcome. Fertil Steril 1997;68:298-304. doi:10.1016/S00150282(97)81519-1

25. Gharavi AE, Harris EN, Asherson RA and Hughes GR. Isotype distribution and phospholipid specificity in the antiphospholipid syndrome. Ann Rheum Dis 1987; 46:1-6. doi:10.1136/ard.46.1.1

26. Rote NS, Johnson D and Branch DW. Ant phospholipid antibodies and recurrent pregnancy loss correlation between the PTT and antibodies against phosphatidylserine and cardiolipin. Am J Obstet Gynecol 1990; 163:575-584. doi: 10.1016/00029378(90)91201-M

27. Wong, L. F., T. F. Porter, and G. R. de Jesús. "Recurrent early pregnancy loss and antiphospholipid antibodies: where do we stand?." Lupus 23.12 (2014): 1226-1228. doi: 10.1177/0961203314529170

28. Crowchock S,Smith B and Gocial B.Antibodies to phospholipids and nuclear antigen in patients with repeated abortion.Am J Obstet Gynecol 1998; 155:1002-1010. doi:10.1016/0002-9378(86)90335-2. 


\section{Original Research Article}

29. Cowchock, Susan, J. Bruce Smith, and Benjamin Gocial. "Antibodies to phospholipids and nuclear antigens in patients with repeated abortions. American journal of obstetrics and gynecology 155.5 (1986): 1002-1010. doi:10.1016/0002-9378(86)90335-2

\section{How to cite this article?}

Nisreen K. Al-Bezrah, ABOG. Antiphospholipid autoantibodies testing in women with unexplained infertility and recurrent first trimester abortion. Obs Rev: J obstet Gynecol 2015;1(1):14-20. doi: 10.17511/joog.2015.i01.04 